\title{
ベンゾオキサジン系耐熱性ネットワークポリマー
}

高橋 昭雄 $*$

\section{Heat Resistant Network Polymers Based on Benzoxazine}

Akio TAKAHASHI*

* 横浜国立大学（） 240-8501 横浜市保土ケ谷区常盤台 79-5)

* Yokohama National University (79-5, Tokiwadai, Hodogaya-ku, Yokohama, Kanagawa 240-8501)

\section{1. はじめに}

ベンゾオキサジンの開環重合によりフェノール性水酸基 を生成するポリベンゾオキサジンは, 新規フェノール樹脂 として注目されている。ポリベンゾオキサジンは従来の フェノール樹脂と同等の耐熱性, 難燃性, 電気特性だけで なく, 分子設計の自由度が高い, 副生成物を発生しない, 高い寸法安定性を持つ, 低熱膨張率であるなど, 多くの特 徵を有する。従来のフェノール樹脂のフェノールはメチレ ン骨格 $\left(-\mathrm{CH}_{2}-\right)$ で結合しているのに対し, ポリベンゾオキ サジンのフェノール性水酸基はマンニッヒ塩基 $\left(-\mathrm{CH}_{2}-\right.$ $\left.\mathrm{N}(\mathrm{R})-\mathrm{CH}_{2}-\right)$ で結合しているため架橋点間距離が長く鞁性 向上にも有利である ${ }^{1)}$ 。また, 分子間・分子内で生じる水 素結合による物理的架橋がセグメントの流動性を抑制して いるために，ポリベンゾオキサジンは一般的な熱硬化性樹 脂に比べ架橋密度が低いにも関わらず，ガラス状態におけ る高い弾性率と高い $\mathrm{Tg}$ を有する ${ }^{2)}$ 。以上の特徴から, 電子 材料, 接着剂, 構造材料など, エポキシ樹脂を代替する材 料としての利用が期待されている ${ }^{3), 4) 。 し か し, ~ ホ ゚ リ ヘ ゙ ン ソ ゙ ~}$ オキサジンは Tg を越えたところで可塑的な挙動を示すこ とや, 重合硬化条件の低減などが課題となっており, さら なる耐熱性の向上も求められている。
ベンゾオキサジンの開環重合により生じたフェノール性 水酸基をエポキシ基と反応させることにより, 低い熱膨張 率 (CTE) の新規熱硬化性樹脂を得る可能性が検討された (Fig. 1)。エポキシ樹脂との反応による架橋構造で熱可塑的 挙動が消失して，さらに高い Tg を有するネットワークポ リマーが得られる5)。

さらに, ベンゾオキサジンによるビスマレイミドの変性 が試みられた。ポリベンゾオキサジンのフェノール性水酸 基はマンニッヒ塩基の影響により反応性が高くビスマレイ ミドの二重結合の重合を促進することが確認された。 $200^{\circ} \mathrm{C}, \quad 4$ 時間の加熱で $300^{\circ} \mathrm{C}$ を超えるガラス転移温度 $(\mathrm{Tg})$ を示すネットワークポリマーが得られている ${ }^{6)}$

改質剤コポリマーのラジカル重合によるポリベンゾオキ サジンの強勒化も試みられた。ベンゾオキサジンの開環重 合の際に，同時に改質剂モノマーであるフェニルマレイミ ドとスチレンのラジカル共重合を行う方法である。フェ ノール基への連鎖移動により改質剤の重合が阻害されるポ リベンゾオキサジン特有の問題を解決するために少量のエ ポキシ樹脂中で改質剤を重合した後, ベンゾオキサジンの 重合系に添加する。また，改質剤モノマーの溶解度パラ メータ (SP 值) に着目し, ベンゾオキサジン存在下でも 改質剤モノマーがラジカル重合する方法も見出され強勒化

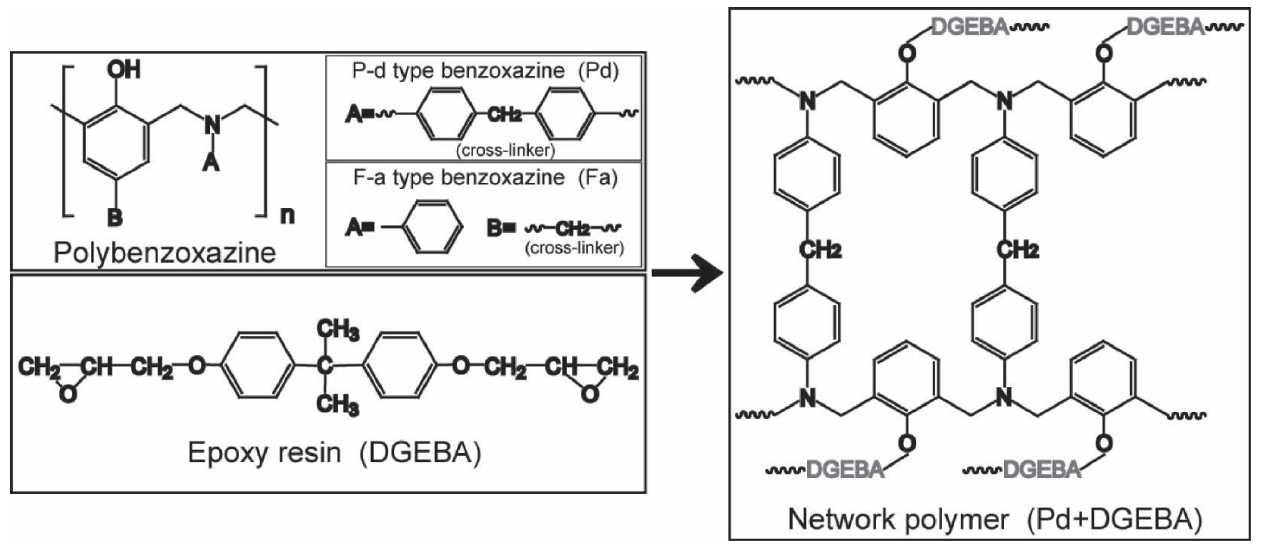

Fig. 1 Reaction of polybenzoxazine with epoxy resin 
に成功している ${ }^{7)}$ 。順次, ポイントを記載して概説とした い。

\section{2. エポキシ変性ポリベンゾオキサジン}

Fig. 2 の 2 種類のベンゾオキサジン 3,3- (メチレン $-1,4-$ ジフェニレン） ビス（3,4-ジヒドロ $-2 \mathrm{H}-1,3-$ ベンゾオキ サジン）(Pd), 2,2-ビス（3,4-ジヒドロ $-2 \mathrm{H}-3-$ フェニル1,3 -ベンゾオキサジニル) メタン $(\mathrm{Fa})$ をそれぞれ単独で硬 化して得られた硬化物の物性を Table 1 にまとめて示す。 $\mathrm{PFa}$ と比較すると, PPd は機械的特性・熱的特性ともに優 れた特性を示す。ベンゾオキサジンの特徴として低 CTEが 知られているが, PPdは $\mathrm{PFa} よ り 9 \mathrm{ppm} / \mathrm{K}$ 低い $44 \mathrm{ppm} / \mathrm{K}$ を示す。また, $\mathrm{Tg}$ に関しても $\mathrm{PPd}$ は $26^{\circ} \mathrm{C}$ 高い $196^{\circ} \mathrm{C}$ を示 す。Fig. 3 に示す重合体の化学構造より, PFaの窒素原子は フェニルペンダントと連結されているのに対し, PPdの窒 素原子はジフェニルメタンと連結し, 主鎖との架橋部位を 構成している ${ }^{8)}$ 。PFaではペンダント状のフェニル基がフェ

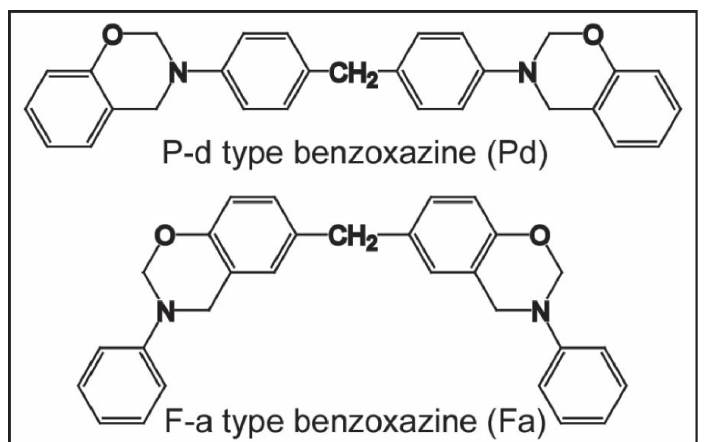

Fig. 2 Chemical structure of benzoxazines
ノール性水酸基の立体障害となり，反応性が低下する一 方, PPdのフェノール性水酸基は立体障害も少なく外側に 向かって位置されるために, 反応性だけでなく, 分子間相 互作用も大きくなるためと考えられる。このような高分子 構造に起因する反応性や分子間相互作用の違いが, PPd と $\mathrm{PFa}$ のポリベンゾオキサジン間での物性に差異をもたらし たと考えられる。

ポリベンゾオキサジン PPd の水酸基当量 1.0 に対して DGEBAのエポキシ当量を 1.0 (PdBA1), 0.5 (PdBA0.5), 0.3 (PdBA0.3) と変え, $200^{\circ} \mathrm{C}$ で 4 時間加熱して得た硬化物物性 を Table 2 に示す。エポキシ当量が小さいほど CTE は低下 し, PdBA0.3 はPdBA1 より $8 \mathrm{ppm} / \mathrm{K}$ 低い $47 \mathrm{ppm} / \mathrm{K}$ を示 す。また Fig. 4 より, エポキシ当量が小さいにも関わらず, PdBA0.3においても熱可塑的な挙動は改善される。さら に, PdBA0.3 は PdBA1 の $\mathrm{Tg}$ を $23^{\circ} \mathrm{C}$ 上回る $206^{\circ} \mathrm{C}$ を示す だけでなく, PPdの $\mathrm{Tg} よ り も 11^{\circ} \mathrm{C}$ 高い值を示した。この ようなエポキシ樹脂の添加量により生じる特性の違いを,

Table 1. Physical properties of polybenzoxazines ${ }^{1)}$

\begin{tabular}{|c|c|c|c|c|c|c|c|c|c|c|}
\hline \multirow[b]{2}{*}{ No. } & \multirow[b]{2}{*}{ Benzoxazine } & \multicolumn{2}{|c|}{ Flexural properties } & \multirow[b]{2}{*}{$\mathrm{n}^{2)}$} & \multirow[b]{2}{*}{$\begin{array}{l}\mathrm{Tg}^{3)} \\
{\left[{ }^{\circ} \mathrm{C}\right]}\end{array}$} & \multirow{2}{*}{$\begin{array}{c}\text { Crosslink } \\
\text { density }{ }^{3), 4)} \\
{\left[\mathrm{kmol} / \mathrm{m}^{3}\right]}\end{array}$} & \multirow[b]{2}{*}{$\begin{array}{c}\mathrm{CTE}^{5,6)} \\
{[\mathrm{ppm} / \mathrm{K}]}\end{array}$} & \multirow[b]{2}{*}{$\begin{array}{l}\mathrm{Td}_{5}{ }^{7)} \\
{\left[{ }^{\circ} \mathrm{C}\right]}\end{array}$} & \multirow[b]{2}{*}{$\begin{array}{l}\operatorname{Td}_{10}{ }^{7)} \\
{\left[{ }^{\circ} \mathrm{C}\right]}\end{array}$} & \multirow[b]{2}{*}{$\begin{array}{c}\text { Residue }^{7) \sim 9)} \\
{[\%]}\end{array}$} \\
\hline & & $\begin{array}{c}\text { Strength } \\
{[\mathrm{MPa}]}\end{array}$ & $\begin{array}{c}\text { Modulus } \\
{[\mathrm{GPa}]}\end{array}$ & & & & & & & \\
\hline PPd & $\mathrm{Pd}$ & $181 \pm 25$ & $6.02 \pm 0.19$ & 3 & 195 & 2.4 & 44 & $323^{9)}, 431^{10)}$ & $323^{9)}, 364^{10)}$ & 53.0 \\
\hline $\mathrm{PFa}$ & $\mathrm{Fa}$ & $157 \pm 13$ & $5.15 \pm 0.08$ & 4 & 169 & 2.7 & 55 & $183^{9)}, 305^{10)}$ & $288^{9)}, 368^{10)}$ & 50.5 \\
\hline
\end{tabular}

1) Curing condition: $200^{\circ} \mathrm{C} / 4 \mathrm{~h} \quad{ }^{2)}$ Number of specimens

${ }^{3)}$ By DVA (heating rate: $5^{\circ} \mathrm{C} / \mathrm{min}$, frequency: $1 \mathrm{~Hz}$ ) ${ }^{4)}$ By rubber state formula $\mathrm{T}$ : $(\mathrm{Tg}+40) \mathrm{K}$

${ }^{5)}$ By TMA (heating rate: $5^{\circ} \mathrm{C} / \mathrm{min}$, under $\mathrm{N}_{2}: 20 \mathrm{ml} / \mathrm{min}$ ) ${ }^{6)}$ Range: $50^{\circ} \mathrm{C} \sim 100^{\circ} \mathrm{C}$

${ }^{7)}$ By TGA(heating rate: $10^{\circ} \mathrm{C} / \mathrm{min}$, under $\mathrm{N}_{2}: 20 \mathrm{ml} / \mathrm{min}$ ) ${ }^{8)}$ At $700^{\circ} \mathrm{C}{ }^{9)}$ Shape of specimens: powder ${ }^{10)}$ Shape of specimens: fragment

Table 2. Physical properties of DGEBA modified $\mathrm{Pd}^{1)}$

\begin{tabular}{|c|c|c|c|c|c|c|c|c|c|c|c|}
\hline \multirow{3}{*}{ No. } & \multirow{3}{*}{ Ar-OH : epoxy } & \multicolumn{2}{|c|}{ Flexural properties } & \multirow{3}{*}{$\mathrm{n}^{2)}$} & \multirow{3}{*}{$\begin{array}{l}\mathrm{Tg}^{3)} \\
{\left[{ }^{\circ} \mathrm{C}\right]}\end{array}$} & \multirow{3}{*}{$\begin{array}{l}\text { Crosslink } \\
\text { density }{ }^{3), 4)} \\
{\left[\mathrm{kmol} / \mathrm{m}^{3}\right]}\end{array}$} & \multirow{3}{*}{$\begin{array}{l}\mathrm{CTE}^{5), 6)} \\
{[\mathrm{ppm} / \mathrm{K}]}\end{array}$} & \multirow{3}{*}{$\begin{array}{l}\mathrm{Td}_{5}{ }^{7)} \\
{\left[{ }^{\circ} \mathrm{C}\right]}\end{array}$} & \multirow{3}{*}{$\begin{array}{l}\mathrm{Td}_{10}{ }^{7)} \\
{\left[{ }^{\circ} \mathrm{C}\right]}\end{array}$} & \multirow{3}{*}{$\begin{array}{c}\text { Residue }^{7), 8)} \\
{[\%]}\end{array}$} & \multirow{3}{*}{ Remark } \\
\hline & & Strength & Modulus & & & & & & & & \\
\hline & & {$[\mathrm{MPa}]$} & {$[\mathrm{GPa}]$} & & & & & & & & \\
\hline PPd & - & $181 \pm 25$ & $6.02 \pm 0.19$ & 3 & 195 & 2.4 & 44 & $323^{9)}, 431^{10)}$ & $364^{9)}, 439^{10)}$ & $53.0^{9)}, 53.2^{10)}$ & Transparent \\
\hline PdBA1 & $1.0: 1.0$ & $173 \pm 11$ & $3.14 \pm 0.34$ & 6 & 183 & 4.2 & 55 & $335^{9)}, 361^{10)}$ & $353^{9)}, 383^{10)}$ & $37.7^{9)}, 41.5^{10)}$ & Translucent \\
\hline PdBA0.5 & $1.0: 0.5$ & $170 \pm 4$ & $4.80 \pm 0.18$ & 4 & 202 & 4.5 & 52 & $335^{9)}, 361^{10)}$ & $353^{9)}, 382^{10)}$ & $40.3^{9)}, 48.0^{10)}$ & Translucent \\
\hline PdBA0.3 & $1.0: 0.3$ & $198 \pm 17$ & $4.47 \pm 0.14$ & 6 & 206 & 3.9 & 47 & $339^{9)}, 359^{10)}$ & $362^{9)}, 375^{10)}$ & $41.4^{9)}, 46.0^{10)}$ & Transparent \\
\hline
\end{tabular}

${ }^{1)}$ Curing condition: $200^{\circ} \mathrm{C} / 4 \mathrm{~h}{ }^{2)}$ Number of specimens

${ }^{3)}$ By DVA (heating rate: $5^{\circ} \mathrm{C} / \mathrm{min}$, frequency: $\left.1 \mathrm{~Hz}\right){ }^{4)}$ By rubber state formula $\mathrm{T}:(\mathrm{Tg}+40) \mathrm{K}$

${ }^{5)}$ By TMA (heating rate: $5^{\circ} \mathrm{C} / \mathrm{min}$, under $\mathrm{N}_{2}: 20 \mathrm{ml} / \mathrm{min}$ ) ${ }^{6)}$ Range: $50^{\circ} \mathrm{C} \sim 100^{\circ} \mathrm{C}$

${ }^{7)}$ By TGA (heating rate: $10^{\circ} \mathrm{C} / \mathrm{min}$, under $\mathrm{N}_{2}: 20 \mathrm{ml} / \mathrm{min}$ ) ${ }^{8)}$ At $700^{\circ} \mathrm{C} \quad{ }^{9)}$ Shape of specimens: powder ${ }^{10)}$ Shape of specimens: fragment 


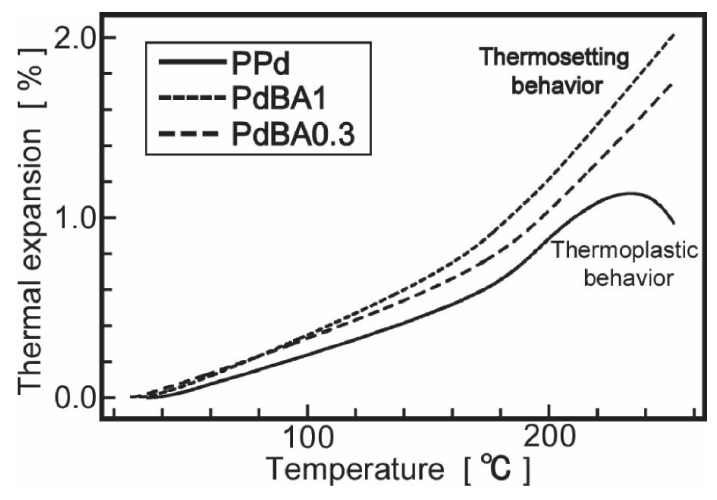

Fig. 4 Thermal expansion behavior of PPd and PdBA (load: $5.0 \mathrm{~g}$, heating rate: $5^{\circ} \mathrm{C} / \mathrm{min}$, under nitrogen: $20 \mathrm{ml} /$ min, curing condition: $200^{\circ} \mathrm{C} / 4 \mathrm{~h}$ )

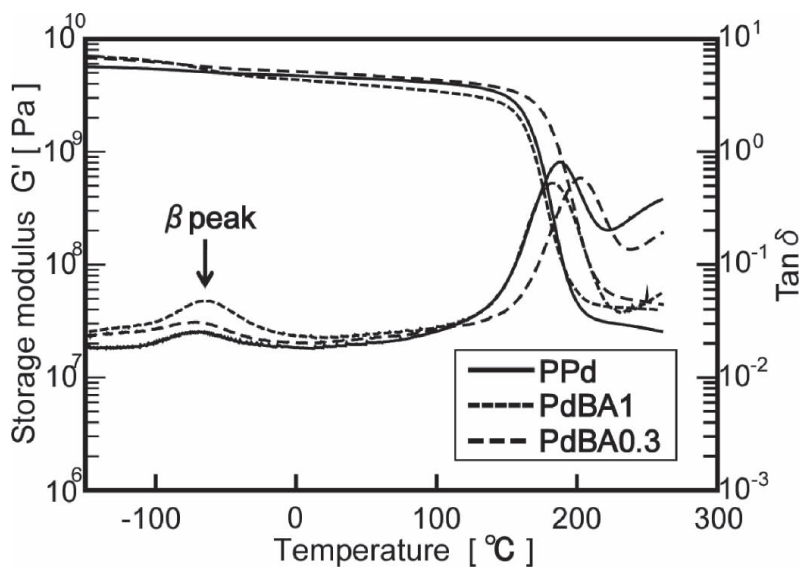

Fig. 5 Dynamic viscoelastic analysis of PPd and PdBA (heating rate: $5^{\circ} \mathrm{C} / \mathrm{min}$, under air, frequency: $1 \mathrm{~Hz}$, curing condition: $200^{\circ} \mathrm{C} / 4 \mathrm{~h}$ )

反応挙動や反応率を用いて解析した結果, ベンゾオキサジ ンの開環率, DGEBAのエポキシ基の反応率ともにエポキ シ樹脂の添加量の最も小さい PdBA0.3 が最も高く上記の結 果が裏付けられている。

しかしながら, Fig. 5 の動的粘弾性測定 (DVA) 結果では, 全てにおいて Tg を超えたゴム状領域が平坦であり, 硬化 は十分に進行していることが示された。つまり, エポキシ 当量が大きい状況下 (PdBA1) では重合が阻害され, 一部分

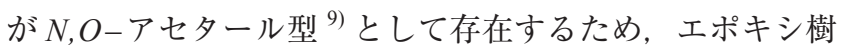
脂との反応に必要なフェノール性水酸基が減少し, オキサ ジン環のマンニッヒ転位 ${ }^{\dagger} へ$ 反応率が低く見積もられた と考えられる。これは Fig. 5 の $-70^{\circ} \mathrm{C}$ 付近にPdBA1 の $\beta$ 緩 和ピークが認められる結果とも一致しており, PdBA1 では 未反応の DGEBA が片末端に側鎖として多く存在している ことが示唆される (Fig. 6(b))。また, Fig. 6 にモデル図とと もにそれぞれの硬化物の密度を示した。密度はPPd が最も 高く, 分子鎖間で相互作用が働いていており, 密にパッキ ングしている可能性が示唆される。PdBA1 の密度は最も低 くなり, Fig. 6 のモデル図に示されるように, 分子間のパッ

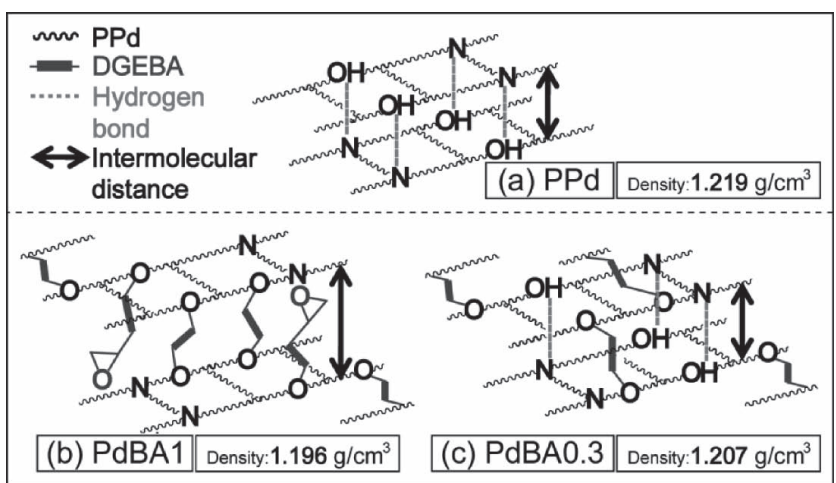

Fig. 6 Chemical structure of compounds

キングがエポキシ樹脂との架橋により阻害されていること が推測される。相関性のある妥当な結果が得られ，その中 で PdBA0.3 はエポキシ樹脂との反応により密度が PPdより わずかに低いが, PdBA1より高いことから, 分子間相互作 用を維持しつつ化学的架橋を組み込んでいると考えられ る。すなわち, 物理的架橋 (水素結合) の中に適量の化学 的架橋が生じることで, PPd の低 CTE を活かし, 且つ, 軟 化も改善され，PPdよりも高い $\mathrm{Tg}$ を有する硬化物を得るこ とができた (Fig. 6(c))。また， 既報 ${ }^{5)} に$ 。述べたように，高耐 熱性の多環芳香族骨格を有するエポキシ樹脂 ${ }^{10)}$ を用いるこ とで, PPd 特有の低 CTE を維持しつつ, さらなる耐熱性の 向上が認められている。

\section{3. ベンゾオキサジン変性ビスマレイミド樹脂}

$\mathrm{SiC}$ パワーデバイスでは, $300^{\circ} \mathrm{C}$ を超える温度での動作 も想定されるため, さらに高耐熱樹脂の出現が望まれてい る。前述のポリベンゾオキサジンの特異な反応を利用して, Fig. 7 に示す芳香族ビスマレイミドを変性するベンゾオキ サジン変性ビスマレイミド樹脂が検討された。具体的に は, その硬化物の剛直な構造から優れた耐熱性を持つ 4,4'ビスマレイミドジフェニルメタン (BMI) と, 重合体がペン ダントな部位を持たず，かつ構造中の芳香環が重合体中で スタッキングを起こすことにより低熱膨張率を示す前述の Pd 型ベンゾオキサジン $(\mathrm{Pd})$ が用いられた。 BMI と Pd は共 に2 官能性でありそれぞれ単独でも三次元網目構造を形成 するが，この 2 つの樹脂は Fig. 8 に示す相互に反応する可 能性も示唆されている。ポリベンゾオキサジンの持つフェ ノール性（マンニッヒ）水酸基とマレイミド二重結合との 反応の可能性が報告されている ${ }^{11)}$ 。さらにベンゾオキサジ ンが持つ 3 級アミン構造や, その硬化中に発生するとされ るフェノキシドなどの求核成分もマレイミドの二重結合を 攻撃すると予想されており，このような BMI と Pd 間の反 応による高耐熱性ポリマーアロイの可能性が調查された。 フェノール (Phenol) とフェニルマレイミド (PMI)を用いた モデル反応の結果, 求核試薬の存在下, Fig. 8 の上部に示 されたマイケル付加による化合物が主生成物として得ら 


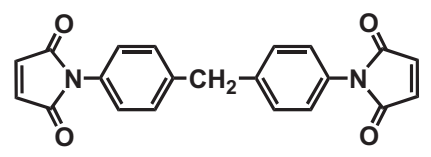

BMI

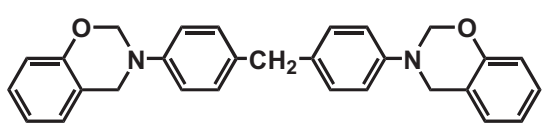

P-d type benzoxazine

Fig. 7 Chemical structure of compounds

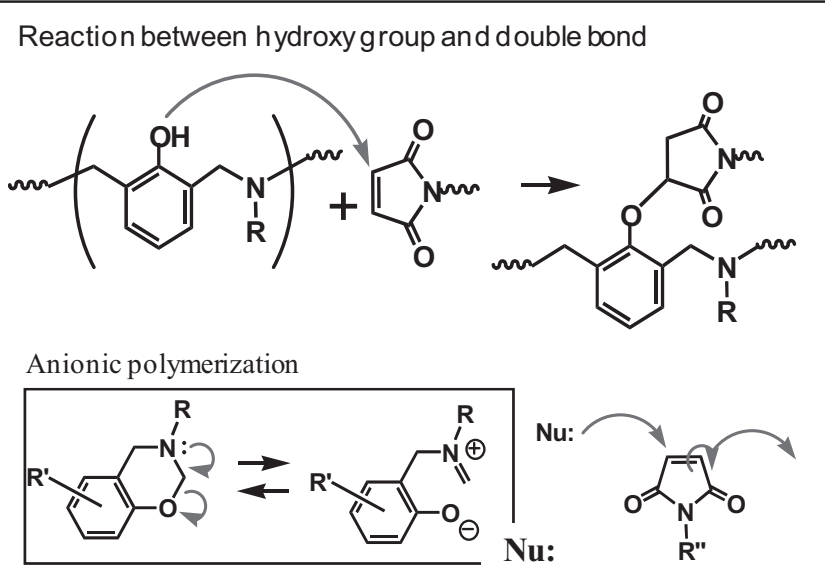

Fig. 8 Reaction between $\mathrm{BMI}$ and Pd

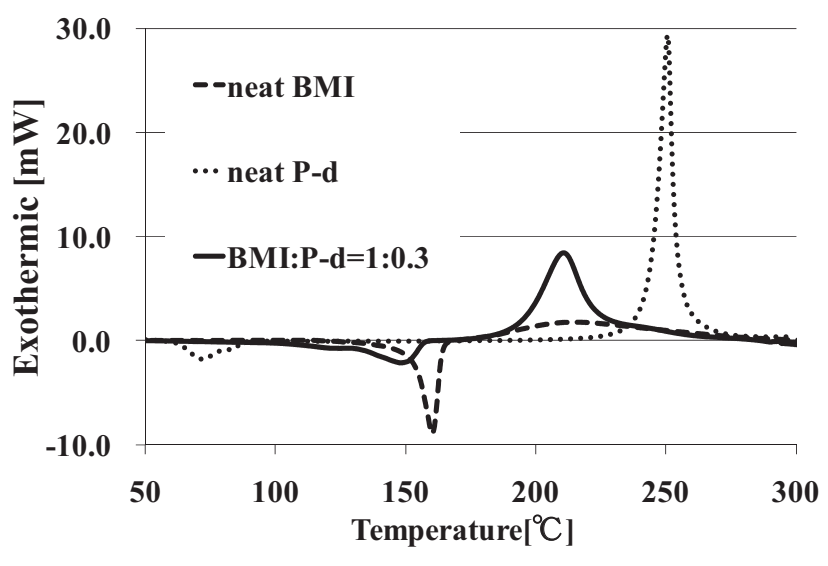

Fig. 9 DSC charts of mixture (BMI:P-d=1:0.3) and neat resins. (heating rate: $10^{\circ} \mathrm{C} / \mathrm{min}$, under $\mathrm{N}_{2}: 50 \mathrm{ml} / \mathrm{min}$ )

Table 3. Thermal properties of mixtures and neat resins

\begin{tabular}{cccccc}
\hline \multirow{2}{*}{ BMI:P-d } & $\mathrm{Tg}^{1)}$ & $\mathrm{CTE}^{2), 3}$ & $\mathrm{~T}_{\mathrm{d} 5}{ }^{4)}$ & $\mathrm{T}_{\mathrm{d} 10}{ }^{4)}$ & Char yield $^{4,5)}$ \\
\cline { 2 - 6 } & $\left({ }^{\circ} \mathrm{C}\right)$ & $(\mathrm{ppm} / \mathrm{K})$ & $\left({ }^{\circ} \mathrm{C}\right)$ & $\left({ }^{\circ} \mathrm{C}\right)$ & $(\%)$ \\
\hline neat P-d & 204 & 41.6 & 314 & 358 & 45 \\
\hline $0.5: 1$ & 213 & 46.1 & 327 & 357 & 48 \\
\hline $1: 1$ & 240 & 46.6 & 334 & 360 & 44 \\
\hline $1: 0.5$ & 271 & 46.5 & 342 & 370 & 44 \\
\hline $1: 0.3$ & 315 & 47.6 & 382 & 408 & 45 \\
\hline $1: 0.2$ & 294,360 & 46.7 & 402 & 425 & 43 \\
\hline neat BMI & 151 & 50.3 & 485 & 500 & 47 \\
\hline
\end{tabular}

${ }^{1)}$ By DVA (heating rate: $5^{\circ} \mathrm{C} / \mathrm{min}$, frequency: $1 \mathrm{~Hz}$ )

${ }^{2)}$ By TMA (heating rate: $5^{\circ} \mathrm{C} / \mathrm{min}$, Under: $\mathrm{N}_{2} 20 \mathrm{ml} / \mathrm{min}$ ) 3 3) Range $50^{\circ} \mathrm{C}$ to $100^{\circ} \mathrm{C}$

4) By TGA (heating rate: $5^{\circ} \mathrm{C} / \mathrm{min}$, Under: $\mathrm{N}_{2} 20 \mathrm{ml} / \mathrm{min}$ ) 5 ) From $35^{\circ} \mathrm{C}$ to $700^{\circ} \mathrm{C}$

れ，マレイミドの二重結合とフェノール性水酸基との反応 性が確認された。DSC 測定の結果は Fig. 9 に示す。BMI と $\operatorname{Pd}$ の単独系チャートはそれぞれ破線と点線で示し, BMI: $\mathrm{Pd}=1: 0.3$ の混合系は実線で示した。混合系チャートは単独 系チャートの単純な重ね合わせではなく, BMI のピークが シャープになり反応性が向上した事や Pdの反応温度の低 温シフトが観測され, BMI-Pd 間での相互反応の可能性が示 唆された。

作製した硬化物の熱的特性を Table 3 に示す。BMI 単独 硬化物の $\mathrm{Tg}$ が低いのは, 本樹脂が本来完全硬化に高温長 時間の加熱を要するために $200^{\circ} \mathrm{C} / 4 \mathrm{~h}$ という限られた硬化 条件では未硬化である為である。しかし, 混合系で単独系 よりも高い Tg を示している事が明らかであり, 特に BMI: $\mathrm{Pd}=1: 0.3$ の系では $200^{\circ} \mathrm{C} / 4$ 時間の加熱条件では $310^{\circ} \mathrm{C}$ の 高い Tg が示された。これは BMI と Pdの相互作用によっ て BMI の硬化性が改善された為だ考えられる。特に Fig.
9 に示したような求核攻撃は BMI に通常の熱ラジカル重合 に加え，アニオン重合を起こさせる可能性があり，反応性 の向上に寄与すると推測される。 $\mathrm{Tg}$ が最高值を取った 1 : 0.3 の系における $\mathrm{T}_{\mathrm{d} 5}, \quad \mathrm{~T}_{\mathrm{d} 10}$ は $382,408^{\circ} \mathrm{C}$ と高い值が示さ れ, この系が物理的・化学的耐熱性共に優れている事が判 明した。さらに熱膨張率も $47 \mathrm{ppm} / \mathrm{K}$ という值が得られ, これは汎用エポキシ樹脂の $70 \mathrm{ppm} / \mathrm{K}$ と比較して十分に低 い值である。

\section{4. ポリベンゾオキサジンの強勒化}

ポリベンゾオキサジンの強勒化に関していくつかの報告 例 ${ }^{12), 13)}$ があるが, 改質剤の in situ 重合法によるポリベンゾ オキサジンの強勒化は未だ報告されていない。本研究で は, in situ 重合法によるポリベンゾオキサジンの強勒化が

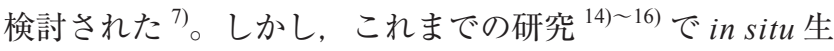
成改質剂として有効であった $N-$ フェルマレイミドース 
チレン交互共重合体 (PMS) のラジカル重合がベンゾオキサ ジンによって阻害されたため, ビスフェノール A 型エポキ シ樹脂 (DGEBA) をラジカル重合の媒体として Fig. 10 に示 すフェニルマレイミド $(\mathrm{PMI})$ とスチレン $(\mathrm{St})$ からなるコポ リマー (iPMS) をin situ生成させる新たな手法によってポ リベンゾオキサジンの強勒化が検討された。この手法では マトリックス樹脂がエポキシ変性ポリベンゾオキサジンと

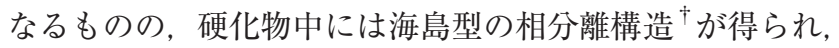
結果として $10 \mathrm{wt} \%$ 量のコポリマーを用いた PB0.3-iPMS10 では破壊勒性值 $\left(K_{\mathrm{IC}}\right)$ が $55 \%$ 向上した。

これとは別に, Fig. 11 にコンセプトを示す SP 值に基づ いて選択したブチルメタクリレート (BuMA), スチレン (St) を改質剤モノマーとして用いる改質剤コポリマー (iPBS) の in situ 重合法による強勒化も達成された。マトリックスで あるポリベンゾオキサジンの SP 值と改質剤モノマーの SP 值の違いを利用して効果的な改質剤コポリマーの相分離を 形成させる試みである。その結果 Table 4 に示すように, PPd-iPBS18G3 では曲げ強度を大きく損なうことなく， $K_{\mathrm{IC}}$ が $43 \%$ 向上した。 $K_{\mathrm{IC}}$, 曲げ強度などの硬化物の物性は 3 $\mathrm{mol} \%$ のマトリックスと改質剤 iPBS との相容性を向上させ ることを目的にグリシジルメタクリレート (GMA) を添加し た際に最も改善されており, GMA 添加の有用性が示され た。GMA 中のエポキシ基と P-d の開環重合によって生成す るフェノール性水酸基が反応し, マトリックスに対する改 質剂の相容性が向上したためであると考えられる。両手法 において強勒化が達成され, それに加えて前者では $200^{\circ} \mathrm{C}$ を超える $T_{\mathrm{g}}$, 後者では $200 \mathrm{MPa}$ を超える曲げ強度を有する 硬化物が得られた。

$K_{\mathrm{IC}}$ 以外の硬化物の物性で比較すると, 前者の DGEBA を 改質剂のラジカル重合の媒体として用いる手法では $200^{\circ} \mathrm{C}$ を超える $\mathrm{Tg}$ を有する硬化物が, 後者の改質剤のラジカル 重合を P-d 中で直接進行させる in situ 重合法では $200 \mathrm{MPa}$ を超える曲げ強度を有する硬化物が得られた。物性面では 両手法ともに一長一短のように見えるが, 成形性の観点か ら鑑みると前者では注型前に改質剤を重合させる必要があ
る一方で, 後者の in situ 重合法はモノマーの添加による低 粘度化で成形性が改善されており， RTM 成型などの大型一 体成形への応用が期待される。さらに，in situ 重合法では 改質剤相へ架橋剤を導入することによって形成される IPN 構造に起因して，より機械特性に改善も見込める。

(2013.5.30- 受理)<smiles>O=C1C=CC(=O)N1c1ccccc1</smiles>

$N$-phenylmaleimide (PMI)<smiles>C=C(C)C(=O)OCC1CC1</smiles>

Glycidyl methacrylate (GMA)

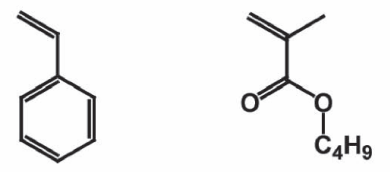

Styrene $n$-Butyl methacrylate (St) (BuMA)

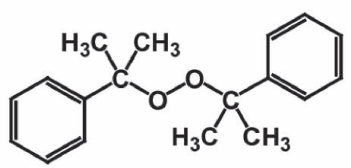

Dicumyl peroxide (DCP)
Fig. 10 Chemical structure of used modifier compounds

a) $\mathrm{SP}$ (matrix) $\fallingdotseq \mathrm{SP}$ (monomer) b) $\mathrm{SP}$ (matrix) $\neq \mathrm{SP}$ (monomer)

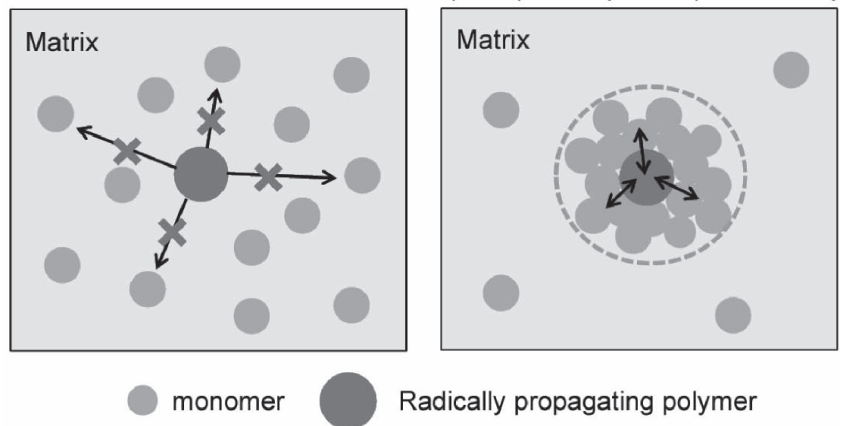

Fig. 11 Schematic illustration of radical polymerization in benzoxazine matrix

Table 4. Mechanical and thermal properties of PPd modified with in situ generated modifiers ${ }^{1)}$

\begin{tabular}{|c|c|c|c|c|c|c|c|c|c|}
\hline \multirow[b]{2}{*}{ No. } & \multirow[b]{2}{*}{$\begin{array}{c}\text { Modifier } \\
{[\mathrm{wt} \%]}\end{array}$} & \multirow[b]{2}{*}{$\begin{array}{l}\mathrm{GMA}^{3)} \\
{\left[\mathrm{mol}^{2} \%\right]}\end{array}$} & \multirow[b]{2}{*}{$\begin{array}{c}K_{\mathrm{IC}} \\
{\left[\mathrm{MN} / \mathrm{m}^{3 / 2}\right]}\end{array}$} & \multirow[b]{2}{*}{$n^{4)}$} & \multicolumn{3}{|c|}{ Flexural properties } & \multirow[b]{2}{*}{$n^{4)}$} & \multirow[b]{2}{*}{$\begin{array}{c}T_{\mathrm{g}}^{5} \\
{\left[{ }^{\circ} \mathrm{C}\right.}\end{array}$} \\
\hline & & & & & $\begin{array}{c}\text { Strength } \\
{[\mathrm{MPa}]}\end{array}$ & $\begin{array}{l}\text { Modulus } \\
\text { [GPa] }\end{array}$ & $\begin{array}{c}\text { Strain } \\
{[\%]}\end{array}$ & & \\
\hline PPd & - & - & $0.77 \pm 0.03$ & 6 & $230 \pm 4$ & $4.92 \pm 0.06$ & 7.3 & 3 & 207 \\
\hline PPd-iPBuMA14 & 14 & - & $0.96 \pm 0.05$ & 4 & $222 \pm 8$ & $4.49 \pm 0.04$ & 7.9 & 4 & 191 \\
\hline PPd-iPS14 ${ }^{2)}$ & 14 & - & $0.92 \pm 0.06$ & 5 & $215 \pm 14$ & $4.75 \pm 0.03$ & 6.8 & 5 & 197 \\
\hline PPd-iPBS102) & 10 & - & $0.94 \pm 0.06$ & 5 & $216 \pm 6$ & $4.70 \pm 0.09$ & 7.0 & 6 & 197 \\
\hline PPd-iPBS14²) & 14 & - & $1.06 \pm 0.04$ & 4 & $233 \pm 16$ & $4.71 \pm 0.14$ & 7.7 & 6 & 193 \\
\hline PPd-iPBS18 $8^{2)}$ & 18 & - & $1.08 \pm 0.01$ & 4 & $203 \pm 2$ & $4.44 \pm 0.06$ & 6.9 & 6 & 192 \\
\hline PPd-iPBS22 $2^{2)}$ & 22 & - & $1.09 \pm 0.03$ & 6 & $194 \pm 9$ & $4.15 \pm 0.11$ & 7.0 & 4 & 191 \\
\hline PPd-iPBS18G32) & 18 & 3 & $1.10 \pm 0.03$ & 4 & $224 \pm 6$ & $4.86 \pm 0.12$ & 7.3 & 5 & 198 \\
\hline PPd-iPBS18G5 $5^{2)}$ & 18 & 5 & $0.90 \pm 0.02$ & 4 & $209 \pm 9$ & $4.80 \pm 0.06$ & 6.7 & 5 & 195 \\
\hline PPd-iPBS18G102) & 18 & 10 & $0.76 \pm 0.01$ & 5 & $205 \pm 9$ & $4.89 \pm 0.06$ & 6.4 & 5 & 194 \\
\hline
\end{tabular}

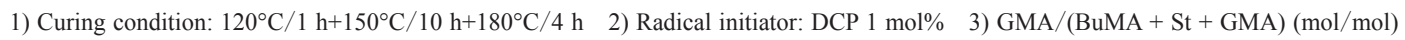

4) Number of specimens 5) By DVA (heating rate: $5^{\circ} \mathrm{C} / \mathrm{min}$, frequency: $1 \mathrm{~Hz}$ under air) 


\section{文献}

1) 竹市 力：“新規なネットワークポリマーとしての高性能ポ リベンゾオキサジン,”ネットワークポリマー, Vol. 27, No. 4, pp. 48-55, 2006

2) H. Ishida and D. J. Allen: "Mechanical characterization of copolymers based on benzoxazine and epoxy," Polymer, Vol. 37, No. 20, pp. 4487-4495, 1996

3) 高橋昭雄: “自動車用電子材料に使われる耐熱性高分子材 料,”ネットワークポリマー, Vol. 33, No. 1, pp. 34-41, 2012

4) C. Sawaryn, K. Landfester, and A. Taden: "Advanced chemically induced phase separation in thermosets: Polybenzoxazines toughened with multifunctional thermoplastic main-chain benzoxazine prepolymers," Polymer, Vol. 52, pp. 3277-3287, 2011

5) 賀川美香, 大山俊幸, 高橋昭雄 : “エポキシ変性ポリベンゾ オキサジンの研究,”エレクトロニクス実装学会誌, Vol. 14, No. 3, pp. 204-211, 2011

6) 高岩玲生, 大山俊幸, 高橋昭雄：“ビスマレイミドーベンゾ オキサジン間反応を利用した耐熱性樹脂,”ネットワークポ リマー, Vol. 33, No. 1, pp. 1-8, 2012

7) 平尾昂平，賀川美香，大山俊幸，高橋昭雄：“改質剤の in situ 重合法によるポリベンゾオキサジンの強勒化, ”ネット ワークポリマー, Vol. 34, No. 1, pp. 19-27, 2012

8) C. H. Lin, S. L. Chang, C. W. Hsieh, and H. H. Lee: “Aromatic diamine-based benzoxazines and their high performance thermosets," Polymer, Vol. 49, pp. 1220-1229, 2008

9) 工藤亮一, 須藤 篤, 遠藤 剛 : “1,3-ベンゾオキサジンの 開環重合によって得られるポリ（N,O-アセタール）の主鎖 転位反応における酸および塩基類の添加効果, ” Polymer Preprints, Japan, Vol. 57, No. 2, pp. 5344-5345, 2008

10）大西裕一, 大山俊幸, 高橋昭雄: “多環芳香族型エポキシ樹 脂の硬化性と熱機械特性, ” 高分子論文集, Vol. 68, No. 2, pp. $62-71,2011$

11) T. Takeichi, Y. Saito, T. Agag, H. Muto, and T. Kawauchi: "High performance polymer alloys of polybenzoxazine and bismaleimide," Polymer, Vol. 49, pp. 1173-1179, 2008

12) H. Ishida and Y-H. Lee: "Synergism observed in polybenzoxazine and poly ( $\varepsilon$-caprolactone) blends by dynamic mechanical and themogravimetric analysis," Polymer, Vol. 42, pp. 6971-6979,
2001

13) C. Sawaryn, K. Landfester, and A. Taden: "Advanced chemically induced phase separation in thermosets: Polybenzoxazines toughened with multifunctional thermoplastic main-chain benzoxazine prepolymer," Polymer, Vol. 52, pp. 3277-3287, 2011

14）菅原大亮，武山秀一，飯島孝雄，大山俊幸，友井正男：“久

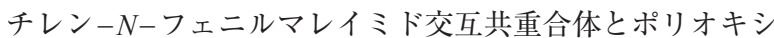
エチレンからなるマルチブロックコポリマーの in situ 生成 による酸無水物硬化エポキシ樹脂の強靱化, ”高分子論文 集, Vol. 63,pp. 720-726, 2006

15）三角 潤，大山俊幸，友井正男，高橋昭雄：“In situ 法を利 用したスチレン - N-フェニルマレイミド交互共重合体とポ リエチレンオキシドからなるグラフトコポリマーによるエ ポキシ樹脂の強鞁化, ”高分子論文集, Vol. 65, pp. 562-572, 2008

16）北村あい, 杉 裕紀, 大山俊幸, 高橋昭雄 : “In situ 重合架 橋型 $N$-フェニルマレイミドースチレン交互共重合体による シアナート樹脂の強鞋化,”ネットワークポリマー, Vol. 31, pp. $299-307,2010$

\section{$\dagger$ 用語解説}

溶解度パラメータ：溶解度パラメータ（ようかいど, Solubility Parameter, $\delta, \mathrm{SP}$ 值）は，ヒルデブラント (Hildebrand)によって導入された正則溶液論により定義 された值であり，2 成分系溶液の溶解度の目安となる。 マンニッヒ転位：マンニッヒ反応は活性な $\alpha$ 水素を持つ 化合物（カルボニル化合物, カルボン酸誘導体, 末端 アルキン，ニトロ化合物，ニトリル化合物など）のイ ミニウムイオンへの求核付加反応。ベンゾオキサジン

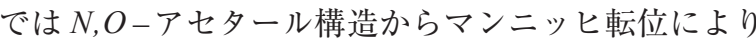
フェノール構造になる。

コポリマー：2 種類以上の異なった単量体の重合（共重 合）によってできた高分子を共重合体（コポリマー） と呼ぶ。

海島型の相分離構造 : 二成分のうち片一方の量がかなり 多い場合に生じる状態で，少ない方の成分が樹脂の内 部に島のように散らばる相分離構造をいう。

高橋昭雄（たかはし あきお） 